\title{
PROGRAM EVALUATION OF THE FREE EDUCATION IN BALANGAN REGENCY
}

\author{
Akhriani \\ Badan Penelitian dan Pengembangan Daerah, Kab. Balangan, Kalimantan Selatan \\ Akhriani.balangan@yahoo.co.id
}

\begin{abstract}
The research is aimed to investigate and analyze the contexts, input, process, and product of the free education program in the regency of Balangan. The research is an evaluative study by employing a CIPP model of program evaluation by Daniel L. Stufflebeam.The data of the study is collected from various sources which include the Education Department, headmasters, teachers, school committees, parents, students, and school documents. The data is collected by utilizing observation, interview, questionnaire, and documentation.The results of the program evaluation show that: 1) the component of context which include the needs, goals, foundations, and program targets have met the evaluation criteria; 2) the component of input which consists of program plan, program structure, program management, and availability of the finance have met the evaluation criteria however the aspect of manpower particularly in the announcement of the finance that the schools have received, the use of the budget, and the announcement of free education through banners have not met the evaluation criteria; 3) the component of process have not met the evaluation criteria particularly the aspect of check clearing which include the indicator of accuracy of financial revenue to the school account, and the involvement of the school committees in designing the RAPS. On the aspect of budget use is the school's announcement on the plan of financial use in the early of academic year. Meanwhile, on the aspect of budget responsibility is the school's announcement on the use of the BOS/BOSDA in the school announcement boards. On the aspect of monitoring, the BOS/BOSDA management in the regency has analyzed the results of the monitoring whereas on the aspect of supervision the BOS/BOSDA management in the regency has carried out supervision to schools; and 4) the component of product involves the decrease of the numbers of the drop out children have met the evaluation criteria because the free education program has caused a significant effect on the decrease of the numbers of drop outs in the regency of Balangan.
\end{abstract}

\section{Keywords: free education, education, the CIPP evaluation model}

Development of education is one of the pillars to form human capital (human capital) in regional development which is no longer an investment in the long term. The achievement of educational development goals, in turn, can improve the quality and productivity of the population, where the population productivity growth is the engine of growth of economic growth and the welfare of the population itself. Through educational investment will be able to improve the quality of human resources shown by increased knowledge and skills that will encourage increased productivity of one's work, and ultimately someone who has high productivity will gain better welfare and avoid poverty.

Improving the level of education is a form of human resource investment. The level of education also affects the level of poverty because education is one component that is emphasized in the cause of the vicious cycle of poverty. One way to overcome this is through basic education, which the government translates into a twelve-year compulsory education program.

This 12-year compulsory education program is a continuation of the 9-year compulsory education program. Therefore, the economic access of Indonesian society is not sufficient to be able to complete education. In fact, for the Indonesian nation's education is actually a commitment between the Government and society, as stated in the 1945 Constitution that the purpose of the state is to educate the life of the nation. The 12year Compulsory Education Policy is in line with the spirit to liberate the Indonesian people from the confines of ignorance and poverty, the only way is education. Article 31 of the 1945 Constitution stipulates that "(1) every citizen is entitled to receive education", and 
"(2) every citizen is obliged to attend basic education and the government shall be obliged to finance it." In fact, the Free Education program accommodates the spirit of education internationally.

The recognition that education is the right of every human being is contained in the Universal Declaration of Human Rights, which in Article 26 paragraph 1 reads "Everyone has the right to education. Education should be free, at least for low school and basic education. Low education should be required. Technical and vocational education in general should be open to everyone and higher education must be accessible in the same way, based on propriety. "As is known, that the implementation of development so far more emphasis on the concept of economic growth, with the assumption that economic growth will benefit humans. But in reality it is not always the case, in the long term high economic growth is important, but what economic growth and for whom. Therefore, in the implementation of development in line with the implementation of regional autonomy, there needs to be a new paradigm that is development that prioritizes aspects of human development.

According to the United Nations Development Program (UNDP), human development is a development model aimed at expanding the choice for people who can be grown through empowerment efforts. This can be achieved through development programs that focus on improving the basic human capability of increasing the health status, in the form of longevity and healthy living, having sufficient knowledge and skills to be used to enhance participation in productive economic activities and earn sufficient income with purchasing power worthy. Based on the above concept, building human means to increase human resources (HR) in a broad sense covering physical and spiritual aspects, material and spiritual in the individual and social scale which in the end must be able to become a comprehensive development resources. As with economic development, human development requires the availability of data analysis for planning and policy-making to be appropriately targeted, as well as to evaluate the extent to which the development implemented can improve the quality of human life as a development object. One measuring tool commonly used is the Human Development Index (HDI) given the vastness of human development, but at least HDI can describe the results of human development implementation according to the three components of a very basic human capacity indicators. These measurements have been used both at the national and international levels in view of the development results of each province or country. Furthermore, this measurement tool is expanded to a lower level at the district / city level.

Departing from the importance of education for all citizens whose estuary is on increasing the number of literacy which is one of the compilers of HDI, then education becomes one of the important priorities in the Regional Medium Term Development Plan (RPJMD) Balangan District Year 2011-2015. One of the efforts taken in the framework of improving the quality of human resources is through the Implementation of Free Education Program in Balangan Regency. Free Education Program has been implemented since the year 2009 until now. Many things have been achieved and also a challenge in the future in an effort to increase literacy rate in Balangan Regency. The district literacy rate in South Kalimantan in 2011 shows that the literacy rate of Balangan Regency is still below the average literacy rate of South Kalimantan Province, which means that Balangan Regency is still a negative contributor to the average provincial literacy rate. Literacy figures for 2011 and 2012 are still diutering 95.66, which means no increase. In addition, this literacy rate significantly correlated positively with the HDI of Balangan Regency, where in 2012 the Balangan Regency Balangan was 67.71 and was in 13 th out of 13 districts / cities in 
South Kalimantan. This becomes a challenge for all stakeholders of Balangan Regency to prioritize the improvement of education quality of Balangan Regency.

Based on the above preliminary data exposure, it is deemed necessary to conduct a more in-depth evaluation of the implementation of Free Education Program related to its effectiveness in the improvement of Human Development Index (HDI) in Balangan Regency.

\section{METHOD}

Based on the program evaluation approach that has been selected and the focus of research that has been established, the method used in this study is qualitative research methods. According Sugiyono qualitative research is a research method based on postpositivism philosophy, is used to examine the condition of natural objects in which the researcher is as a key instrument, the collection of data sources is done purposively, data collection techniques triangulation, data analysis is inductive / Qualitative and more emphasizing the meaning of the generalization (Sugiyono, 2009). According to Bogdan and Taylor as quoted by Moleong argued that the qualitative method as a research procedure that produces descriptive data in the form of written or oral words of the people and behavior that can be observed (Moleong, 2007). Meanwhile, according to Moleong qualitative research is a study that intends to understand the phenomenon of what is experienced by research subjects such as behavior, perception, motivation, action, etc., holistically, and by way of description in the form of words and language, A unique natural context and by utilizing natural methods (Moleong, 2007) Further described by Williams as quoted by Moleong that qualitative research is the collection of data in a natural setting, using natural methods, and done by people or researchers who are naturally attracted (Moleong, 2007).

Qualitative research aims to obtain a complete picture of a thing according to the views of the human being studied. Qualitative research is related to the ideas, perceptions, opinions or beliefs of the people studied and all can not be measured by numbers.

Sudjana said that the evaluation of a program using a qualitative approach has characteristics: (a) the subject being evaluated or the source of data is a natural context, (b) the evaluator being the main instrument, (c) descriptive and narrative, (d) finding meaning behind the behavior And (f) prioritizing the acquisition of data from the source directly (primary); and (f) the triangulation effort, ie checking the validity of the data by obtaining data from other sources and using various instruments (Sudjana, 2008)

Based on the information obtained from the evaluation results, it is expected to provide input for improving the character education program in schools, especially in primary schools. As Anderson cited by Komarudin suggest that evaluation aims to help refine or develop better programs and assess their impacts for policy determination (Komarudin, 2012). In line with the above understanding, the final goal to be achieved in this research is to improve the free education program in Balangan Regency so that it can improve the Human Development Index (HDI) in Balangan Regency.

In accordance with the substance to be studied, the evaluation model used is the CIPP model developed by Stufflebeam. Stufflebeam as quoted Widoyoko said that CIPP stands for context, input, process, and product (Widoyoko, 2009). 


\section{Context}

\section{RESULT}

The results obtained through interviews with parents of learners about the need for a Free Education Program show that parents learners are in need of financing assistance for their son / daughter. They hope the local government holds the responsibility in handling and fulfilling the cost of tuition fees (SPP), school uniforms, textbooks, school equipment, honorariums for non-civil servant teachers. Principally learners expect that parents to send their children / parents are no longer free of charge.

The community's need for Free Education Program in Balangan Regency is inseparable from the society's perception on the importance of education for their son / daughter. This is understandable as their knowledge and experience gained from various sources increases with the development of information and communication technology.

Parents' perceptions of children's formal education are related to their needs and life goals and past experiences. This happens to parents of learners with weak economic backgrounds as well as learners' parents from a strong economic background. Results of field research indicate that the families or parents of learners from middle to lower economic background have a high need for Free Education Program in Balangan Regency. Thus it can be concluded that the needs of the community Balangan District Free Education Program is very high.

On the side of the local government of Balangan Regency itself, the community's need for education has been responded with the issuance of Local Government Regulation No. 2/2010 on Education in Balangan Regency. (2) People with physical, emotional, mental, intellectual, and / or social impairments are entitled to special education, (3) Population in the area Isolated or underdeveloped, and remote indigenous peoples are entitled to special service education, (4) People with special intelligence and talents are entitled to special education, (5) Every citizen is entitled to the opportunity to promote lifelong education.

The local government's response to the demands (needs) of the community for education is further underscored by prioritizing local government obligations related to education sphere. It is stated in the local regulation that (1) the local government has the obligation to provide services and facilities, and ensure the implementation of quality education for every citizen without discrimination, (2) The local government shall ensure the availability of funds for the implementation of primary and secondary education for every population aged seven Up to eighteen years (Regional Regulation of Balangan Regency Number 2 Year 2010 (article 13)). As well as a responsive public policy, the Balangan District Regulation No. 2 of 2010 is in line with what Frank Fischer has stated, "Accounts that broadly fall under the responsive government label point to the different ways in which the government responds to external pressure for change. Governments take some form of opinion as a 'thermostat' and respond by seeking to establish congruence between public demands and policy outputs. (Fischer, et al., 2007) Responsive government refers to different ways in which governments respond to external demands for change. Governments need to build links between public demand and policy outcomes.

In the public policy perspective of the nature of policy responsiveness, Martin Lodge mentions there are three approaches (Fischer, et al., 2007). First, in a purely responsive form of government, policy is seen as a response to the importance of the public. Thus, a broader anti-tax majority coalition within the broader voter layer is said to push for a longterm shift toward different mixed-on policies of inflation and acceptable levels of unemployment. On the other hand, governments that are responsive to public demands are 
directly perceived as bad, for example in the field of risk management where criticism focuses on short-term moral panic responses. This is seen in the low interest in continuing education on school-age children found in some communities in Balangan District even though it has been facilitated by the local government through the Balangan District Free Education Program at the beginning of the policy of School Operational Assistance grant. However, as the policy progresses gradually the community's need for adequate education increases.

Second, and arguably represents the most established research tradition in comparative public policy, is a matter of concern to interested parties. Research in this tradition has traditionally focused on macro-economic trends of both left and right parties rather than central parties (Hibbs 1977; Castles 1982; Blais et al. 1996; Berry and Lowry 1987) (in Fisher, 2007) or on whether party policy impacts On the ultimate government policy (Laver et al., 2003) (in Laver and Benoit, 2003). With regard to the former, there is only limited evidence, for example, Richard Rose more than two decades ago emphasized that an exaggerated inheritance, in the form of marginal change of party that government can make (Rose 1990). Others show changes in boundaries that provide clear evidence of partisan preferences.

Third, it is "as a rule [...] acquired by industry and designed and operated primarily for its benefit side" (Stigler 1971, 3). Although Statements such as universal law have been modified from time to time, it still refers to established traditions in political science that emphasize the importance of special interests in the development of public policy, across sectors and countries. Similar interests, though based on a very different research approach, relate to the literature within the policy network and claims about the importance of features of the policy network (such as the difference between problem networks and the policy community). Another type of special interest is "coalition advocacy" (Sabatier 1988) and other forms of coalitions from various organizations and individuals. Comparative Public Policy is united by this general policy belief system. It seems that the community's need for Free Education Program in Balangan Regency does not need a complex explanation that traces to the interests of political parties that actually display contestation of political interests but not so far. In simple terms it can be interpreted that the launch of the Free Education Program policy is solely on the first model of the policy responsive nature of education. This can be read through the process of implementation of the Free Education Program policy in Kabupaten Balangan which does not involve elements of political parties.

\section{Input}

Public policies such as the Free Education Program in Kabupaten Balangan are not independent of the academic process of policy in order for the policy to be effective. At the level of implementation of socialization policy to the stakeholders becomes a necessity. Research data indicates that the socialization of the Free Education Program has taken place with results that can be understood by the stakeholders. The data also shows that schools as education providers are able to apply the knowledge of the results of socialization into activities that are in compliance with the guidelines for the provision of Free Education Program assistance in the form of financing items that are permitted in the provision of funds for Free Education Program.

But in the socialization of Free Education Program, there are still some parents of learners who have not fully understand the existence, purpose, allocation of funds, and the nature of the Free Education Program. The result is that parents are unable to distinguish 
which costs are being assisted by the local government and where the costs of education are personal, such as the purchase of supporting books, internet access outside the school.

The socialization of public policy is the dissemination of information (programs, regulations, policies) from one party (program maker) to other parties (stakeholders and the general public) and empowerment process, which is expected to increase knowledge, foster critical awareness, change attitudes, and The behavior of the party targeted by the socialization.

Judging from its objectives, socialization in general aims to make the public understand and able to interpret the 'meaning' of the concepts and objectives of government policy, the wider community knows and understands the progress of the implementation of government programs as part of the responsibility to the public, - empowerment activities contained in the program cycle of government policy. While the specific objective of socialization is for the existence of commitment and cooperation between the district government and the community to plan, implement and monitor / supervise jointly, it can stimulate the interest of strategic groups and caring groups to take action both in cooperation and establish community-based oversight, and Disseminating the results of the development of government programs to the wider community.

Relying on the nature of socialization, if one element of the target group (in this case the parents of learners) has not fully understood the nature of the program offered, then the objectives of socialization may be achieved but not perfect. The parents of learners in addressing the Free Education Program in Balangan Regency can not be expected to explore the meaning of the program. They also have a perception that expectations for free education have not received a positive response from the local government of Balangan Regency.

The final group of Free Education Program objectives-in this case parents and students-is reflected also from the information of the Free School Management Program Management Team who stated that the socialization of the program is presented to the School Committee which is considered as a representation of the parents of students by phone or SMS (short message service). This short service medium via mobile phone has a level of effectiveness that is less effective given the limitations of communication messages that can be delivered. In addition, the school considers that the parents of learners is not an urgent need because in the end parents of learners will know the policy of this Free Education Program when students are not charged education fees.

This finding suggests that there has been no effective policy communication between policy makers and public policy parties. Whereas communication between policy makers and policy-makers is an important element in every policy implementation. This is inseparable from the concept of community policy.

Policies are determined by the most influential, the most concerned, the most expert, or the most psychologically minded of policy issues, whether they want to continue the status quo or intend to radically change. The policy community signifies a policy process in which interests are organized and government actors play a major role in shaping the direction and outcomes of public policy. The policy community is neither a market nor a hierarchy, but a pluralistic societal policy environment.

Based on this, the targeted party (the parents of the students) should be positioned in the main priority of the socialization of the Free Education Program for the direction and the expected policy outcome when the policy is formulated. In other words, the socialization of Free Education Program needs to reach the main target of the policy in the 
form of the program so that the parent learners also fully understand the core message of Free Education Program in Balangan Regency.

\section{Process}

Free Education Program in Balangan Regency welcomed by the community will meet the effectiveness of the policy if the elements of the policy process of the program takes place in an orderly manner. The process of Free Education Program policy highlighted in this study includes the disbursement of funds in accordance with the time set, the school receiving Free Education Program has a School Development Plan (RPS), the school successfully developed School Budget Activity Plan (RKAS) by using RPS as a consideration, The school succeeded in making the RKAS by involving the School Committee, the Free Education Program taking was done by the Principal and Treasurer known by the School Committee, and the school managed to collect data on poor students.

The disbursement of Free Education Program funds is made referring to the funding instructions for Free Education Program. Procedures undertaken for it are through actions with stages of data collection, determination of allocation of Free Education Program for budgeting in APBD, determination of allocation for each school, preparation of fund disbursement, fund distribution, and fund raising.

Viewed from the aspect of the program's disbursement time schedule, the Free Education Program is highly dependent on the schedule of funds disbursement of Free Education Program from the central government because the Free Education Program is not fully funded by the local government. The central government itself every year always makes a schedule of funds disbursement Free Education Program that is communicated to the regions so that regions can prepare themselves in terms of mechanisms, personnel, funds from the region itself. However, the schedule that has been submitted is not fully in accordance with the distribution. This is because in the early days of the revolving funding policy of the Free Education Program of the region hampered the technical constraints of disbursement of regional funds for the program, many schools that do not have accounts, reporting data of recipients of Free Education Program funds have not done or less complete, related data Not match.

The delay in disbursement of Free Education Program funds for 2015 occurred in the first quarter which occurred not only in Balangan District in South Kalimantan Province but also in other districts / cities. Any delay in payment of this program resulted in disruption of the process of education in schools because operational costs can not be overcome by schools that do not have operational funding outside the Free Education Program fund.

A number of schools are forced to take steps by seeking debt either through teachers or principals. But some are forced to use other postal funds to cover school operating costs. As revealed by the Head of SMPN 1 Paringin. He confirmed that until now there has been no clarity when the disbursement of Free Education Program funds for the 2015 quarter. "There has been no outflow at all for the quarter this year, if in 2014 smoothly," he said. School efforts to cover operational costs that usually use the Free Education Program funds are forced by teachers. Teachers commit unjustifiably to cover the shortage of school operational costs and when the program funds are disbursed, some of them are used to be returned to teachers who bail the funds.

\section{Product}

Evaluation of Minimum Service Standards Education in the District of Balangan, referring to the Regulation of the Minister of National Education RI No. 15 Year 2010. Results of research on minimum service standards in Balangan Regency can be described 
as follows: Based on the data in Table ... it can be seen that the average achievement of SPMBP for SD / MI is $60.04 \%$, the achievement of SPMBP for SMP / MTs is $62.29 \%$, and the achievement for SD / MI and SMP / MTs is 58.81\% All of which have not achieved results in accordance with the Minimum Service Standards for Education (SPMBP). Associated with the Free Education Program these achievements show that the Free Education Program has not succeeded in boosting educational services in Balangan Regency.

Indeed Free Education Program funded by Free Education Program fund is not solely aimed at providing educational services according to the standards set by the government because the allocation of funds Free Education Program mainly is to help alleviate the burden of costs that must be borne by parents of learners so that children, School-aged children may receive education up to the level of primary education and keep children in school to remain in school until graduation. That is, with Free Education Program funds no more school-aged children are not in school and no children drop out of school due to economic reasons. Nevertheless, central and local government funding previously allocated to finance education services and the operation of schools with the Free Government Education Program funds can improve education services with more funds.

In fact, so far the minimum standard of educational service has yet to be achieved. Whereas with the standard services made possible the quality of education and equity of education will be improved. The results of the research on SPMBP can then be used to: formulate a comprehensive plan on (1) Free Education Program of Education Unit: Efforts to support the adequacy of school operational needs provided by the Government based on the method of calculating operational cost of education unit to achieve the standard of service determined in accordance with the price (2) DGP (Proportional Teacher Distribution): Efforts to implement the arrangement and equity of civil servant teachers to ensure the availability and qualification of teachers in each school can meet established service standards, (3) SBM (School Based Management) : Efforts to improve the management of school management / educational units to be more transparent, accountable, participatory and responsive so as to provide good services and make sustainable improvements.

The Free Education Program in Kabupaten Balangan was held for the purpose of assisting the school's operational costs which were expected to free the parents of the students from the school fees and keep the students to school until they finished their education. However, from the data of the research results it is still seen that the drop out rate still exists (2.4\% for SD / MI and 3.22\% for SMP / MTs). This shows that the Free Education Program has not fully achieved the goals associated with the elimination of drop out rates in primary education in Balangan District. It is known that the dropout rate is not all due to economic problems, especially the inability of parents to pay for their children, but in addition to economic problems there is still a reason that boys should help make a living in their families and this is considered natural for The weak economic community. Children used by parents to share the burden of the needs of the whole family if the family income, both father and mother, is not sufficient to cover expenses to buy daily necessities.

The presence of a child in the family is valued for some of the values described in the concept of Value of Children (VOC) by Hoffman, L.W. And Hoffman, M.L (in Suckow \& Klaus, 2007) that the value of the child is a parent's view and expectation of the child related to the needs of the parents (Zulfitri, 2013). Cagitcibasi (in Zulfitri, 2013) describes some of the values that the parent possesses can be summarized into three types, 
among others; A) utilitarian value, which is related to the material benefit of the child, both when the child is young and when the child is mature; B) psychological value, which is related to satisfaction such as happiness, pride, compassion and togetherness that children give to parents; And c) social value, that is, referring to the social acceptance gained by married couples when having children (Zulfitri, 2013). In the context of Free Education Program, the problem of drop out children with the reason to help families in earning a living outside the scope of the program because the program funding assistance through the Free Education Program is intended to finance the operational of schools which is only able to overcome the cost of education for the child concerned. Meanwhile, the family's daily needs are assumed to have been addressed by the family. This needs to get the attention of local policymakers in trying to address education services for all residents and improve the quality of education in the regions.

The problem is also in the Free Education Program is the absence of drop out rates due to the absence of fees for children to keep children in school. At a glance this is contradictory between the availability of funds to provide free education from local government and not yet covered all school-age children who are still active school to continue their education. However, when viewed from the drop out rates due to the proximity of the child's distance to school, this can be understood. A great distance from home to school leads to additional costs for parents for transporting from house to school. For poor families, the burden of transport costs is so burdensome that they have no choice but to choose their children to drop out rather than divert their daily expenditures that are no longer possible to use for the transportation of children in school. This means that the Free Education Program fund has not reached transportation expenses for school children overall.

\section{CONCLUSION}

Based on the results of evaluation and discussion that have been described in Chapter IV can be found some findings and conclusions as follows:

Firstly, based on the policy context component of the Free Education Program in Kabupaten Balangan has been implemented in accordance with the needs, objectives of the drafting and policymakers, the community and schools as the providers of education, both early childhood education (PAUD), primary education (Primary and Secondary Schools / MTs), and secondary education (SMA / MI / SMK / SMALB). This is in line with the juridical foundation of the implementation of Free Education Program in Balangan Regency. Implementation of the Free Education Program policy has also been able to accommodate the aspirations of the developing community in terms of the mindset and progress of the times. The Free Education Program Policy in Kabupaten Balangan has been able to raise public awareness of the importance of education, so this policy needs to be continued in order to improve educational equity and broader education quality.

Secondly, the overall input component of the Free Education Program has been able to deliver program implementation to the achievement of results and to solidify the foundation of an aspirational Free Education Program. The accumulation of results from the aspects of the policy input component of the Free Education Program can be said to encourage effective and efficient program management. Aspects of the policy input components of the Free Education Program, such as planning, implementing structures, management, human resources, and costs have been the support of robust program implementation with few weaknesses such as fulfillment of achievements that are not fully conformed to the formulation of concepts in program design. 
Third, the components of the process in which the aspects are evaluated, ie the disbursement of funds, the use of funds, the accountability of the use of funds, monitoring, and overall supervision proceeds well in the sense that the process component is practiced in earnest has been able to make the policy of Free Education Program give meaning Educative in all walks of life and bureaucratic ranks as program implementers, although at the implementation level the program faces several obstacles and shortcomings.

Fourth, the product components whose aspects of Minimum Service Standards for Education and drop-out rates have taken place with tangible results. Minimum Service Standards The field of education provides constructive feedback to policymakers, policy implementers and stakeholders so as to serve as a material and comprehensive evaluation consideration of the Free Education Program.

Some obstacles and shortcomings and problems arise when the implementation process of the program progresses, but has been able to overcome and underlined by the parties concerned about the running of Free Education Program in Balangan Regency with the intention of becoming valuable input if the government later Balangan Regency want to continue and improve This Free Education Program.

Based on the results of the evaluation, data analysis, and findings in this study, the recommendations are given to the policy makers in this case the Regional Government and Central Government, the implementing organization of policy in Balangan Regency, the implementing organization of the school program, and the school committee.

Based on the results of the evaluation of the overall Free Education Program which has been going on with some strengths, weaknesses, opportunities and threats but has achieved good results with some notes, it is recommended that the Free Education Program in Balangan District continues with various ways that can be done To reduce the weaknesses and threats to the implementation of Free Education Program in Balangan Regency. Some more concrete suggestions are given, namely the intention and commitment to achieve the goal of Free Education Program needs to be maintained and improved so that efforts made for it can also improve the efficiency and effectiveness of achieving the goals.

Implementing organization of Free Education Program is a party whose position is very strategic in order to achieve the goal of Free Education Program itself. Therefore, some suggestions need to be addressed, namely the need for active involvement among all implementing personnel so that the tasks and responsibilities can be met optimally. Filling the positions in the District Education Program Free Management Team and the Free School Management Program Management Team need to be upgraded and followed according to the strongly formulated indicators that have not been done optimally.

School-level Implementing Organizations (in this case the School Management Team Free Education Program) spearhead the success of the Free Education Program as a whole. Therefore, some suggestions are submitted, namely the need to improve the discipline of the process in carrying out the stages of activities in accordance with technical guidelines in order to avoid mistakes in the implementation of the Free Education Program implementation.

The School Committee is a partner of formal education that can play a more important and qualified role towards the realization of a successful Free Education Program. Therefore, some suggestions are given, namely the need to increase the active role in guarding the policy in the form of inputs, complaints, and suggestions for the Free Education Program in Balangan Regency. 


\section{REFERENCES}

Anderson, Scarvia B., Samuel Ball, dan Richard T. Murphy. The Profession and Practice of Program Evaluation. San Fransisco: Jossey-Bass Publisher, 1978.

Arikunto, Suharsimi dan Cepi Syafrudin Abdul Jabar. Evaluasi Program Pendidikan. Jakarta: Bumi Aksara, 2008.

Arikunto, Suharsimi. Dasar-Dasar Evaluasi Pendidikan. Yogyakarta: Bumi Aksara, 2008.

Belasen, 2008 dalam Ongkane Sombounkhanh, 2014. "Strategic stakeholder communication within international organization: The case of ASEAN, Laos and the implementation of the ASEAN's strategic plan." Thesis. Unitec Institute of Technology.

Biro Pusat Statistik. Balangan Dalam Angka. Biro Pusat Statistik Kabupaten Balangan, 2012.

Bluntschli, Johan Kaspar. 2000. The Theory of the State. First published in German in 1875 as Lehre vom modernen Stat. First English Edition published 1895. This edition published 2000, by Batoche Books, 52 Eby Street South, Kitchener, Ontario, N2G 3L1. Canada

Djaali dan Pudji Muljono. Pengukuran dalam Bidang Pendidikan. Jakarta: Grasindo, 2000.

Dunn, William N. Public Pulicy Analysis: An Introduction. 4th Edition. New York: Pearson Education, 2011.

Egon G. Guba dan Lincoln, Yvonna S. Effective Evaluation, Improping the Evaluation Result Trough Responsive and Naturalistic Approach. California: Jossey-Bass Publisher, 1981.

Fidler, et al. 1997. Choices for Self-Managing Schools - Autonomy and Accountability. London: Paul Chapman Publishing Ltd.

Fischer, et al., 2007. Public Administration and Public Policy: A Comprehensive Publication Program. New York: CRC Press.

Kaufman, Roger dan Susan Thomas. Evaluation Without Fear. London: New Viewpaints, 1980.

Kementerian Pendidikan dan Kebudayaan. Petunjuk Teknis Penggunaan dan Pertanggungjawaban Keuangan Dana Bos Tahun Anggaran 2014. Jakarta: Kemendikbud, 2013.

Komarudin. "Evaluasi Program dan Pengembangan Pelaksanaan KTSP di SMAN 68 dan SMAN 50 Jakarta.” Disertasi, Universitas Negeri Jakarta, 2012.

Laver, Michael and Kenneth Benoit. 2003. "Extracting Policy Positions from Political Texts Using Words as Data”. American Political Science Review Vol. 97, No. 2 May 2003

Miles, Mathew B., dan A. Michael Huberman. Analisis Data Kualitatif, terjemahan Tjetjep Rohendi Rohidi. Jakarta: Universitas Indonesia Press, 1992.

Moleong, Lexi J. Metode Penelitian Kualitatif. Bandung: Remaja Rosdakarya, 2007. 
OECD, 2002. Glossary of Key Terms in Evaluation and Results-Based Management. Paris: OECD/DAC.

OECD, The Definition and Selection of Key Competencies. <https://www.oecd.org/pisa/35070367.pdf > diakses 7 Agustus 2015.

Peraturan Daerah Kabupaten Balangan Nomor 2 Tahun 2010 tentang Pendidikan Di Kabupaten Balangan.

Peraturan Menteri Pendidikan dan Kebudayaan Republik Indonesia Nomor 161 Tahun 2014 tentang Petunjuk Teknis Penggunaan dan Pertanggungjawaban Keuangan Dana Bantuan Operasional Sekolah Tahun Anggaran 2015

Romo, Soemitro. Perlukah Sekolah Gratis. Jakarta: Rineka Cipta, 2007.

Sevilla, Consuelo G,Jesus A. Ochave, Twila G. Punsalan, Bella P. Regala dan Gabriel B. Uriarte. Pengantar Metoda Penelitian, terjemahan Alimuddin Tuwu. Jakarta: Universitas Indonesia, 1993.

Stufflebeam, Daniel L., dan Anthony J. Shinkfield. Systematic Evaluation: A SelfInstuction Guide to Theory and Practice. Boston: Kluwer Nijhoff Publishing, 1986.

Sugiyono. Metode Penelitian Bisnis: Pendekatan Kuantitatif, Kualitatif, dan R \& D. Bandung: Alfabeta, 2009.

Tayibnapis, Farida Yusuf. Evaluasi Program dan Instrumen Evaluasi. Yogyakarta: Rineka Cipta, 2008.

Tow, Charlene, 2006. The Effects of School Funding on Student Academic Achievement A Study of California School Districts 2000-2004. University of California, Berkley.

United Nations Development Programme, 2009. Handbook of Planning, Monitoring and Evaluating for Development Results. New York: UNDP.

Widoyoko, S. Eko Putro. Evaluasi Program Pembelajaran: Panduan Praktis Bagi Pendidik dan Calon Pendidik. Yogyakarta: Pustaka Pelajar, 2009.

Worthen, Blain R., James R., Sanders, dan Jody L.Fitzpatrick, Program Evaluation Alternative Approach and Practical. New York: Longman, 1997.

Zulfitri, Nurvita Meisakh. "Studi Deskriptif : Nilai Anak Bagi Orang Tua yang Memiliki Anak Tunggal”. Jurnal Ilmiah Mahasiswa Universitas Surabaya Vol.2 No.2 (2013). 